\title{
Penerapan Pembelajaran Kooperatif Tipe Jigsaw Berbasis Online Learning untuk Meningkatkan Hasil Belajar Nahwu
}

\author{
1.Khairil Anwar, ${ }^{2}$ Muhammad Zaky Sya'bani \\ ${ }^{1}$ STIT Darul Fattah Bandar Lampung, ${ }^{2}$ STIT Darul Fattah Bandar Lampung \\ 1.Khairila@darulfattah.ac.id, 2.mzaky@darulfattah.ac.id
}

\begin{abstract}
This research is not only back grounded by the difficulty of students in understanding the rules of grammatical of Arab ic language, but also pay attention to government circulars related to distance learning or in the Network so many schools have to implement Online Learning-based learning in each of their subjects Based on that background, researchers are interested in applying learning with jigsaw types. Based on Online Learning on the learning of grammatical of Arab ic language rules the students' understanding of the grammatical of Arab ic language rules increased. The purpose of this study is to know the application of cooperative learning with jigsaw types based on Online Learning in understanding the grammatical of Arab ic language rules. The subjects of this study were grade VIII D students of 28 students. And this research was conducted in 3 cycles. Based on the results of student evaluation tests in cycle 1 , cycle 2 and cycle 3 can be concluded that the application of learning with jigsaw type is quite instrumental in improving students' understanding of grammatical of Arab ic language rules because the average value of all aspects of grammatical of Arab ic language understanding taught has increased The average test score of all aspects of the pretest was 5.19 and then rose to 9.08 on cycle 1 tests, rising to 9.46 and on cycle 2 and rising to 10.15 . Thus the average overall value of aspects from pretest to cycle 1 tests increased by $3.89 \%$ and from cycle 1 tests to cycle 2 tests increased by $0.38 \%$ and from cycle 2 tests to cycle 3 tests increased by $0.69 \%$.
\end{abstract}

Keywords: Cooperative Learning, jigsaw, Online Learning

\begin{abstract}
ABSTRAK
Penelitian ini tidak hanya dilatarbelakangi oleh sulitnya para siswa dalam memahami kaidah nahwu, namun juga memperhatikan edaran pemerintah terkait pembelajaran jarak jauh atau dalam Jaringan sehingga banyak sekolah harus menerapkan pembelajaran berbasis Online Learning dalam setiap mata pelajarannya. Berdasarkan latar belakang tersebut peneliti tertarik untuk menerapkan pembelajaran dengan tipe jigsaw berbasis Online Learning pada pembelajaran kaidah nahwu agar pemahaman para siswa terhadap kaidah nahwu meningkat.Tujuan dari penelitian ini adalah untuk mengetahui penerapan pembelajaran kooperatif dengan tipe jigsaw berbasis Online Learning dalam memahami kaidah nahwu. Subjek penelitian ini yaitu para siswa kelas VIII D yang berjumlah 28 siswi. Penelitian ini dilaksanakan dalam 3 siklus. Berdasarkan hasil tes evaluasi siswa pada siklus 1, siklus 2 dan siklus 3 dapat diambil kesimpulan bahwa penerapan pembelajaran dengan tipe jigsaw cukup berperan dalam meningkatkan pemahaman siswa terhadap kaidah nahwu karena perolehan nilai rata-rata dari keseluruhan aspek pemahaman nahwu yang diajarkan mengalami peningkatan. Nilai rata-rata nilai hasil tes
\end{abstract}


dari keseluruhan aspek pada pretes adalah 5,19 lalu naik menjadi 9,08 pada tes siklus 1 , naik menjadi 9,46 dan pada siklus 2 dan naik menjadi 10,15. Dengan demikian rata-rata nilai keseluruhan aspek dari pretes ke tes siklus 1 meningkat sebesar 3,89\% dan dari tes siklus 1 ke tes siklus 2 meningkat sebesar $0,38 \%$ dan dari test siklus 2 ke tes siklus 3 meningkat sebesar $0,69 \%$.

Kata kunci: Pembelajaran Kooperatif, jigsaw, Online Learning

\section{PENDAHULUAN}

Bahasa Arab adalah bahasa Al-Qur'an, bahasa informasi dan komunikasi antar umat manusia. Peranan bahasa Arab tidak hanya sebagai alat komunikasi manusia dengan sesamanya, tetapi juga merupakan alat komunikasi manusia beriman dengan Allah, yang berwujud dalam bentuk ritual ibadah umat islam. Mata pelajaran Bahasa Arab merupakan suatu mata pelajaran yang memiliki kedudukan yang sangat strategis dalam pengembangan ilmu-ilmu keislaman. Seorang guru bahasa Arab selain harus mahir dan memiliki pengetahuan berbahasa Arab , juga harus mempunyai keterampilan untuk mengajarkan bahasa Arab . Dalam pelaksanaannya pemberian pelajaran bahasa Arab sekarang ini tidak hanya diajarkan di pondok-pondok pesantren saja tetapi sudah dikembangkan dalam lembaga pendidikan formal bahkan dicantumkan dalam mata pelajaran tersendiri di sekolah-sekolah

Namun, meskipun bahasa Arab sudah masuk dalam mata pelajaran tersendiri di sekolah-sekolah, tidak semudah membalikkan telapak tangan bagi siswa untuk dapat menyerap, memahami, serta menguasai materi bahasa Arab yang telah diajarkan. Banyak siswa yang merasa kesulitan dalam menyerap dan memahami, apalagi menguasai materi bahasa Arab yang telah diajarkan oleh gurunya. Hal tersebut didukung oleh pendapat Suja'i bahwa pembelajaran bahasa Arab dewasa ini masih menghadapi berbagai persoalan, baik dari sisi media maupun metode pembelajarannya. Kendala tersebut dapat terlihat dari hasil atau nilai materi pelajaran bahasa Arab yang telah diperoleh siswa yang belum maksimal. Bahkan sebagian dari mereka belum mencapai tujuan yang diharapkan.

Kondisi tersebut tentu tidak dapat dibiarkan terus menerus, akan tetapi membutuhkan solusi yang baik, sehingga kompetensi bahasa Arab yang dimiliki siswa menjadi baik dan dapat diandalkan terutama kompetensi siswa dalam memahami kaidah bahasa Arab. Ini mengingat bahwa kaidah merupakan hal yang penting dalam pembelajaran bahasa Arab, yang mana dengan memahami kaidah maka seseorang akan mampu memahami bahasa Arab dengan tepat dan benar. Kesulitan dalam memahami 
materi bahasa Arab terutama kaidah nahwu dasar juga dialami oleh siswi kelas VIII D MTs Daarul Huffazh Gedong Tataan Pesawaran. Banyak hal yang menjadi permasalahannya. Sarana dan prasarana yang tidak memadai menjadi salah satu faktornya. Disamping itu, kosakata bahasa Arab yang mereka miliki juga sangat minim. Mengantuk dalam belajar dan tidak mengerjakan tugas adalah kendala selanjutnya. Sehingga hasil belajar bahasa Arab masih dibawah rata-rata. Informasi ini diperoleh berdasarkan wawancara yang dilakukan peneliti terhadap guru bidang studi bahasa Arab di kelas tersebut. Berdasarkan hasil observasi yang dilakukan peneliti dengan guru bahasa Arab Madrasah Tsanawiyah (MTs) Daarul Huffazh Gedong Tataan Pesawaran tersebut, bahwa di kelas VIII-D kriteria ketuntasan hasil belajar bahasa Arab belum maksimal karena dilihat dari hasil nilai ujian semester ganjil memiliki nilai rata-rata bahasa Arab dibawah 70. Hal ini berdasarkan rekapitulasi nilai semester ganjil bahwa dari 24 siswi hanya 2 siswi yang mendapat nilai sangat baik (antara 80-88), 7 siswi mendapat nilai baik (antara 70-74), 8 siswi mendapat nilai cukup (antara 60-68) dan 7 siswi mendapat nilai kurang (antara 48-50).

Salah satu model pembelajaran yang dirasa cukup tepat bagi peneliti untuk diterapkan dalam pembelajaran kaidah nahwu dasar di kelas VIII D MTs Darul Hufaz adalah pembelajaran kooperatif dengan tipe jigsaw, dimana siswa sebagai subjek belajar yang aktif, namun guru tetap memegang peranan penting sebagai pembimbing dan motivator. Dengan pemilihan metode ini, hasil pembelajaran diharapkan lebih bermakna dan siswa dapat termotivasi. Namun dikarenakan adanya surat edaran Menteri Pendidikan dan Kebudayaan Republik Indonesia Nomor 4 tahun 2020 tentang pembelajaran jarak jauh (Daring) maka peneliti menerapkan sistem Online Learning dalam metode pembelaran kooperatip tipe Jigsaw ini.

Pembelajaran kooperatif merupakan strategi belajar dengan sejumlah siswa sebagai anggota kelompok kecil yang tingkat kemampuannya berbeda. Dalam menyelesaikan tugas kelompoknya, setiap siswa anggota kelompok harus saling bekerja sama dan saling membantu untuk memahami materi pelajaran. Dalam pembelajaran kooperatif, belajar dikatakan belum selesai jika salah satu teman dalam kelompok belum menguasai bahan pelajaran. Adapun langkah pembelaran dalam penelitian ini adalah sebagai berikut:

1. Langkah-langkah Pembelajaran Koopertif

Langkah-langkah pembelajaran kooperatif yang terdiri dari 6 fase, yaitu : 
a) Menyampaikan tujuan dan memotivasi siswa.

b) Menyajikan informasi.

c) Mengorganisasikan siswa ke dalam kelompok-kelompok belajar.

d) Membimbing kelompok bekerja dan belajar.

e) Evaluasi.

f) Memberikan penghargaan.

2. Penerapan Pembelajaran Kooperatif Tipe Jigsaw berbasis Online Learning Untuk pelaksanaan pembelajaran kooperatif tipe jigsaw berbasis Online Laerning, disusun langkah-langkah pokok sebagai berikut; (1) pembagian tugas, (2) pemberian lembar ahli, (3) mengadakan diskusi, (4) mengadakan kuis. Adapun langkah-langkah penerapan teknik jigsaw menurut Arends, antara lain adalah:

a) Guru membagi siswa menjadi beberapa kelompok, setiap kelompok terdiri dari 4 - 6 siswa dengan kemampuan yang berbeda. Setelah kembali kekelompok asal, siswa bergantian mengajarkan teman dalam kelompok asal tentang materi pelajaran yang dipelajari atau didiskusikan dalm kelompok ahli tadi dengan menggunakan aplikasi google meets.

b) Setelah siswa berdiskusi dalam kelompok ahli maupun kelompok asal, selanjutnya dilakukan presentasi masing-masing kelompok atau dilakukan pengundian salah satu kelompok untuk menyajikan hasil diskusi kelompok yang telah dilakukan agar guru dapat menyamakan persepsi pada materi pembelajaran yang telah didiskusikan dengan menggunakan aplikasi google meets.

c) Guru memberikan kuis terkait materi Nahwu yang didiskusikan dan dipelajari kepada siswa secara individual dengan menggunakan aplikasi Google Form.

d) Guru memberikan penghargaan pada kelompok melalui skor penghargaan berdasarkan perolehan nilai peningkatan hasil belajar individual dari skor dasar ke skor kuis berikutnya.

Sedangkan Materi Nahwu yang akan diterapkan oleh peneliti adalah ilmu yang membahas baris atau harokat akhir sebuah kata, apakah dia mabni (tetap), mu'rob (berubah), marfu', mansub, majrur atau majzum. Dengan kata lain apakah baris atau harokat akhir sebuah kata berupa dommah, fathah, kasroh atau sukun. Mengingat nahwu merupakan suatu kaidah yang membahas tentang tugas/kedudukan suatu kata dalam kalimat bahasa Arab, maka berikut ini dijelaskan secara ringkas mengenai pembagian kata dalam bahasa Arab yang sangat terkait erat dengan kaidah nahwu. Ada sedikit 
perbedaan dalam istilah bahasa yang digunakan oleh bahasa Indonesia dengan yang digunakan oleh bahasa Arab . Istilah kalimat dalam bahasa Indonesia berbeda dengan kalimat dalam bahasa Arab. Dalam bahasa Arab, kalimat itu sama artinya dengan kata dalam bahasa Indonesia. Sedangkan yang kita sebut sebagai kalimat dalam bahasa Indonesia, maka kalau dalam bahasa Arab ia disebut sebagai jumlah. Kata atau kalimat dalam bahasa Arab dibagi menjadi tiga bagian, yaitu:

a. Isim atau آَإنْنُ

Isim adalah setiap kata yang menujukkan atas manusia, hewan, tumbuhan, benda mati, tempat, masa, sifat, atau mkna mujarrad dari waktu ke masa. Isim terdiri dari 2 macam, yaitu :

1. Isim Mudzakkar, yaitu isim yang menunjukkan laki-laki, bisa berupa nama orang laki-laki seperti: يحيى ،سلمان atau nama benda yang tidak berakhiran ta' marbuthoh (ة), seperti قلم- باب.

2. Isim Muannats, yaitu isim yang menunjukkan perempuan, bisa berupa nama orang perempuan seperti : فاطمة - عائشة juga bisa berupa nama berakhiran ta' marbuthoh (ة), seperti خريطة - ساعة . Isim ditinjau dari jumlah individu atau personnya- terbagi menjadi tiga macam, yaitu :

a) Isim mufrod adalah isim yang menunjukkan atas satu individu mudzakkar, contohnya : عُرَرُ (Umar), atau menunjukkan atas satu individu muannats, contohnya : نَافَذِّة : (Jendela).

b) Mutsanna adalah isim yang menunjukkan atas "dua" individu baik mudzakkar atau muannats dengan tambahan I (alif) dan (nun) atau - (ya') yang berharakat fathah huruf sebelumnya dan ن (nun), contohnya

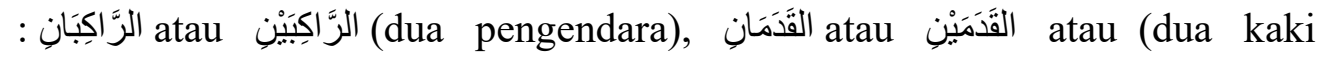
pengendara), Terkadang huruf(nun) diakhir isim mutsanna dihapus/dibuang, contohnya : قَََََّْه (dua kakinya).

c) Jamak adalah isim yang menunjukkan atas jumlah individu yang lebih dari

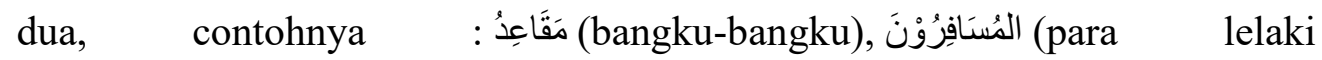
musafir), المسَافِرَاتُ (para wanita musafir).

3. Adapun tanda-tanda isim (عَلاكَّات الإسندِ ) adalah sebagai berikut:

a) Berakhiran Tanwin, contoh : البيت كبيرٌ (rumah itu besar). Maka lafadz كبير adalah isim karena berakhiran dengan tanwin. 
b) Berawalan alif lam ( al / البيت كبير : الب ), contohaka lafadz البيت, adalah isim karena berawalan dengan al / ال

c) Dimasuki huruf jar/khofadh, contoh: القلم على المكتب (pulpen itu diatas meja), maka lafadz المكتب itu isim karena didahului oleh huruf jar berupa

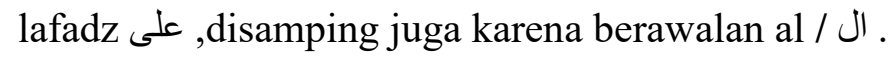

b. Fi'il atau آلَفِعُْ

$F i$ 'il adalah kata yang menunjukan pekerjaan disertai dengan keterangan waktu. Contoh: جلس/dia telah duduk, يجلس/dia sedang duduk, جلس /duduklah. Fi'il terdiri dari 3, yaitu:

1. Fi'il madhi kata kerja lampau, dan tandanya adalah dibaca fathah huruf akhirnya. Contoh: نام الطفل (anak laki-laki itu telah tidur) رجع عمار (Ammar telah pulang). Dan untuk perempuan tinggal tambahkan ta' ta'nits (ت). Misal : نامت بنت (anak perempuan itu telah tidur).

2. Fi'il Mudhori' kata kerja sekarang atau yang akan datang, dan tandanya adalah di awali dengan salah satu dari huruf mudhoro'ah yaitu hamzah nun ya dan ta (أن,ري,ت), dan salah satu cirri-cirinya adalahberharakat dhommah di akhirnya. Cتئلُ : أرجع:saya sedang pulang. Contoh berawalan nun berawalan hamzah يغتسلُ : kami sedang belajar bahasa Arab . Contoh yang berawalan ya / اللغة العربية / maryam / تجلس مريم : hasyim sedang mandi. Contoh yang berawalan ta هلـم sedang duduk.

3. Fi'il amr (فعل أمر)/ kata kerja perintah, dan salah satu cirinya adalah dibaca dengan sukun di akhirnya, misal; إدجل (duduklah) إدخل (masuklah). Tanda-tanda fi'il (عَلَمَات الفِعْل) adalah sebagai berikut:

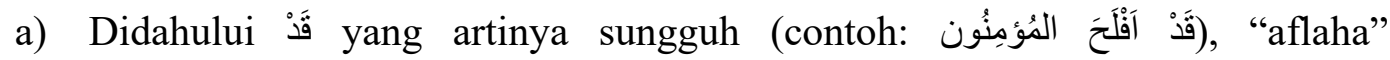
merupakan fi'il karena didahului oleh "qod".

b) Didahului oleh $\square$ yang artinya akan (contoh: سَيَقُوْلُ السفهاءُ merupakan fi' il karena didahului "sin"

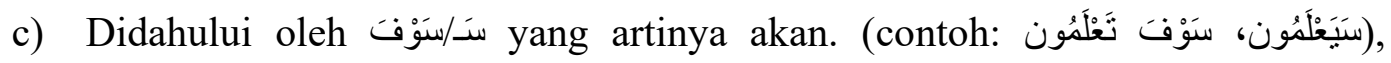
"ta'lamuuna" merpakan fi"'il didahului "saufa".

d) Ada ta ta'nits yang disukunkan. Ta ta'nits tidak memiliki arti khusus, hanya huruf tambahan saja. Ta ta'nits ini merupakan ciri fi'il madhi هِيَ (contoh : تكَتَ)

c. Harf atau 
Harf merupakan bagian dari kata-kata. Atau dengan istilah lain kata adalah kumpulan dari huruf-huruf. Dalam bahasa indonesia harf disebut dengan huruf. Harf terbagi menjadi dua, yaitu:

1. حرف مباني (huruf hijaiy) adalah huruf hijaiyah. Disebut juga dengan حرف حِجَاءِيٌُ (أببـتث : (huruf mabaniy), yaitu huruf yang bisa membentuk satu kata. Contoh

2. حرف معاني (huruf ma'aniy), adalah huruf-huruf yang telah mempunyai arti. Contoh: و - او-ثم-من-اذا. Tanda-tanda harf (عَلَامَات الحَرَف) adalah tidak memiliki ciri isim maupun fi'il. Tidak memiliki makna jika tidak disambungkan dengan isim atau fi'il.

Kunci memahami suatu bahasa adalah dengan cara memahami pola atau struktur kalimatnya. Struktur kalimat inti dalam Bahasa Arab minimal harus tersusun dari dua kata: Pola kalimat Isim + isim, pola kalimat ini disebut dengan jumlah ismiyyah. Yaitu kalimat yang diawali dengan isim. Contoh : هَذَا كِنَّبٌ Pola kalimat fi'il + Isim disebut jumlah fi'liyyah. Yaitu kalimat yang diawali dengan fi'il. Contoh : ذَهَبَ أَحْمَدُ

\section{METODE PENELITIAN .}

Secara teoritis penelitian ini diharapkan dapat menambah pengetahuan penulis mengenai penerapan pembelajaran kooperatif khususnya dalam pembelajaran bahasa Arab secara Online. Dan hasil penelitian ini diharapkan dapat memberikan sumbangan pemikiran bagi para kepala madrasah, khususnya para guru bahasa Arab dalam pembelajaran bahasa Arab berbasis Online Learning.

Secara praktis dapat memberikan manfaat bagi kepala madrasah, khususnya para guru bahasa Arab dalam pembelajaran bahasa Arab, melalui penelitian ini tentunya semoga dapat menambah pengembangan khasanah keilmuan. Karena itu diharapkan dapat memberikan sumbangan pemikiran untuk mengembangan ilmu pendidikan khususnya dalam pembelajaran bahasa Arab serts dapat membantu para praktisi pendidikan dalam upaya meningkatkan kualitas pendidikan di Indonesia.

Penelitian ini menggunakan Penelitian Tindakan Kelas (Classroom-Based Action Research) atau yang lazim disebut PTK, atau dengan kata lain bahwa dalam penelitian ini peneliti dalam melasanakan penelitiannya berkolaborasi dengan guru mitra atau guru bidang study. Penelitian ini berlokasi di MTs Daarul Huffazh Gedong Tataan Pesawaran. Dan subjek penelitian ini adalah siswi kelas VIII D semester genap di MTs tersebut dengan jumlah 28 siswi. 
Pengumpulan data pada penelitian ini dilakukan dengan menggunakan teknikteknik berikut ini :

1. Observasi, Pada tahap observasi peneliti mengamati kegiatan pembelajaran yang berlangsung. Hasil pengamatan dituangkan dalam bentuk catatan lapangan. Catatan lapangan merupakan catatan yang dibuat oleh guru tentang peristiwaperistiwa penting dalam pembelajaran segera setelah pembelajaran tersebut selesai.

2. Dokumentasi, Digunakan untuk memperoleh data data-data yang berhubungan dengan tujuan dalam penelitian.

3. Wawancara, Wawancara adalah sebuah dialog yang dilakukan oleh interviewer (pewawancara) untuk mengetahui informasi dari terwawancara. Wawancara dilakukan setelah proses pembelajaran untuk memperoleh data tentang pembelajaran kooperatif dan pengetahuan siswa berkenaan dengan kaidah nahwu.

4. Angket, digunakan untuk memperoleh data tentang pengetahuan nahwu siswa dan juga data untuk mengetahui implikasi dari penerapan pembelajaran tipe jigsaw dalam meningkatkan pemahaman nahwu siswa.

Teknik analisis data yang digunakan dalam penelitian ini adalah teknik analisis deskriptif kualitatif, yaitu mendiskripsikan data yang diperoleh melalui instrument penelitian. Data hasil observasi pembelajaran dianalisa sejak penelitian dimulai dan dikembangkan selama proses refleksi sampai proses penyusunan laporan. Sedangkan data hasil belajar siswa (tes) dianalisis menggunakan teori dan konsep yang bersifat umum. Penghitungan data hasil tes pemahaman kaidah nahwu setiap siswi dirumuskan dengan :

$$
N=\frac{\text { Nilai Total }}{\text { Nilai Maksimal }} \times 100
$$

\section{Keterangan :}

- N : Nilai

- Nilai total : Skor keseluruhan yang diperoleh siswa

- Nilai maksimal : Skor total maksimal

Sementara untuk mengetahui persentase keberhasilan pemahaman kaidah nahwu siswi dihitung dengan menggunakan rumus : 


$$
\begin{aligned}
& X=\sum \frac{Y}{N} \\
& \text { Dimana : } \quad X \quad=\text { mencari nilai rata-rata } \\
& \Sigma \quad \text { = jumlah seluruh nilai siswa } \\
& \text { N = jumlah seluruh siswa }
\end{aligned}
$$

\section{HASIL DAN PEMBAHASAN}

Penelitian ini dilaksanakan dalam tiga siklus yang masing-masing siklus terdiri dari tiga pertemuan secara Online. Tes tertulis dilaksanakan pada pertemuan ketiga pada setiap siklusnya. Pada pembahasan ini diuraikan tentang hasil tes siswa yang diperoleh pada pretes, siklus 1, siklus 2 dan siklus 3. Hasil dari tes-tes tersebut disajikan pada tablel berikut :

Tabel 1.1. Nilai rata-rata siswi dari siklus pertama sampai siklus ketiga.

\begin{tabular}{|l|c|c|c|}
\hline \multicolumn{1}{|c|}{ Aspek yang Dinilai } & Tes & Tes & Tes \\
Siklus 1 & Siklus 2 & 84,28 & 93 \\
\hline $\begin{array}{l}\text { Menjelaskan istilah } \\
\text { kaidah nahwu }\end{array}$ & 81,42 & 91,42 & 100 \\
\hline $\begin{array}{l}\text { Menyebutkan } \\
\text { kedudukan kata dalam } \\
\text { kalimat pola }\end{array}$ & 89,28 & 89,28 & 90,74 \\
\hline $\begin{array}{l}\text { Menerapkan dalam } \\
\text { kaidah nahwu } \\
\text { kalimat }\end{array}$ & 83,57 & $\mathbf{9 , 4 6}$ & $\mathbf{1 0 , 1 5}$ \\
\hline \multicolumn{1}{|c|}{ Rata-rata } & $\mathbf{9 , 0 8}$ & & \\
\hline
\end{tabular}

Tabel 1.2. Perolehan Hasil Tes dari siklus pertama sampai siklus ketiga. (dalam persen)

\begin{tabular}{|l|r|l|c|c|c|}
\hline $\begin{array}{c}\text { Aspek yang } \\
\text { Dinilai }\end{array}$ & No & Kategori & Tes Siklus 1 & Tes Siklus 2 & Tes Siklus 3 \\
\hline \multirow{2}{*}{$\begin{array}{l}\text { Menjelaskan } \\
\text { istilah kaidah } \\
\text { nahwu }\end{array}$} & 1. & Baik Sekali & 75 & 67,85 & 89,28 \\
\cline { 2 - 6 } & 2. & Baik & - & - & - \\
\cline { 2 - 6 } & 3. & Cukup & 7,14 & 28,57 & 10,71 \\
\cline { 2 - 6 } & 4. & Kurang & - & 3,57 & - \\
\hline
\end{tabular}




\begin{tabular}{|c|c|c|c|c|c|}
\hline & 5. & Sangat Kurang & 3,57 & - & - \\
\hline \multirow{5}{*}{$\begin{array}{l}\text { Menyebutkan } \\
\text { kedudukan } \\
\text { kata dalam } \\
\text { kalimat }\end{array}$} & 1. & Baik Sekali & 100 & 92,85 & 100 \\
\hline & 2. & Baik & - & 3,57 & - \\
\hline & 3. & Cukup & - & - & - \\
\hline & 4. & Kurang & - & - & - \\
\hline & 5 . & Sangat Kurang & - & 3,57 & - \\
\hline \multirow{5}{*}{$\begin{array}{l}\text { Menerapkan } \\
\text { pola kaidah } \\
\text { nahwu dalam } \\
\text { kalimat }\end{array}$} & 1. & Baik Sekali & 85,71 & 89,28 & 100 \\
\hline & 2. & Baik & - & - & - \\
\hline & 3. & Cukup & 10,71 & 10,71 & - \\
\hline & 4. & Kurang & - & - & - \\
\hline & 5. & Sangat Kurang & - & - & - \\
\hline
\end{tabular}

Berdasarkan data di atas dapat diketahui bahwa nilai hasil tes para siswi meningkat dari siklus pertama sampai siklus ketiga, dengan uraian sebagai berikut: Dari siklus pertama nilai rata-rata pada aspek menjelaskan kaidah nahwu 81,42. Dari tes siklus 1 ke tes siklus 2 meningkat dari 81,42 menjadi 84,28. Dan dari tes siklus 2 ke tes siklus 3 meningkat dari 84,28 menjadi 93,57. Aspek menyebutkan kedudukan kata dalam kalimat: Pada tes siklus 1 naik menjadi 100\%, pada siklus 2 menurun menjadi 92,85\% dan pada siklus ke 3 naik kembali menjadi 100\%. Untuk nilai dengan kategori baik hanya ditemui pada siklus ke 2 yakni sebesar 3,57\%. Untuk nilai dengan kategori kurang sebesar $35,71 \%$ pada pretes. Untuk nilai dengan kategori sangat kurang ditemui pada pretes yakni sebesar 35,71\% dan pada tes siklus 2 sebesar 3,57\%. Dari tes siklus 1 nilai rata-rata pada aspek ini meningkat dari 30,71 menjadi 89,28. Dari tes siklus 1 ke tes siklus 2 meningkat dari 89,28 menjadi 91,42. Dan dari tes siklus 2 ke tes siklus 3 meningkat dari 91,42 menjadi 100. Aspek menerapkan pola kaidah nahwu dalam kalimat: pada tes siklus 1 naik menjadi 85,71\%, pada siklus 2 menjadi 89,28\% dan pada siklus 3 nai menjadi $100 \%$. Untuk nilai dengan ketegori cukup pada pretes sebesar $25 \%$ lalu pada siklus 1 naik menjadi $10,71 \%$ dan pada siklus 2 sama yakni 10,71\%. Nilai dengan kategori kurang hanya terdapat pada pretes yakni sebesar 3,57\%. Dan Nilai dengan kategori sangat kurang hanya terdapat pada pretes yakni sebesar 14,28\%. Dari pretes ke tes siklus 1 nilai rata-rata pada aspek ini meningkat dari 70 menjadi 83,57. Dari 
tes siklus 1 ke tes siklus 2 meningkat dari 83,57 menjadi 89,28. Dan dari tes siklus 2 ke tes siklus 3 meningkat dari 89,28 menjadi 90,74.

Rata-rata nilai hasil tes dari keseluruhan aspek pada pretes adalah 5,19 lalu naik menjadi 9,08 pada tes siklus 1 dan naik lagi pada test siklus 2 menjadi 9,46 kemudian naik lagi pada test siklus 3 menjadi 10,15. Ini berarti kenaikan rata-rata nilai keseluruhan aspek dari pretes ke tes siklus 1 adalah 3,89 (0,389\%), dari tes siklus 1 ke tes siklus 2 adalah $0,38(0,0038 \%)$ dan dari tes siklus 2 ke tes siklus 3 adalah $0,69(0,069 \%)$.

\section{KESIMPULAN}

Berdasarkan hasil analisis penelitian ini bahwa penerapan pembelajaran kooperatif dengan tipe jigsaw berbasis Online Learning pada pembelajaran nahwu dikelas VIII D MTs Darul Hufadz dapat meningkatkan hasil belajar siswa terhadap kaidah nahwu yang diajarkan. Hal ini terlihat dari meningkatnya rata-rata nilai tes yang dilaksanakan pada pretes, siklus 1, siklus 2 dan siklus 3. Peningkatan rata-rata nilai tes dari pretes ke siklus 1 adalah sebesar 3,89\% dan peningkatan rata-rata nilai tes dari siklus 2 ke siklus 3 adalah sebesar $0,69 \%$.

\section{DAFTAR PUSTAKA}

Ainin, M. Dkk. 2006. Evaluasi dalam Pembelajaran Bahasa Arab. Malang: Misykat Anwar, Khairil, 2019, Buku Percakapan Bahasa Arab Dengan Pendekatan Kontekstual, Jurnal Annaba ; Pemikiran dan Penelitian Pendidikan Islam, 2 (2), $31-40$

Aqib Zainal. 2008. Penelitian Tindakan Kelas.Bandung; Yrama Widya.

Arikunto, Suharsimi. 1992. Dasar-dasar Evaluasi Pendidikan. Jakarta: Bumi Aksara.

Fatonah, Siti. Blangko Nilai Ujian Bahasa Arab Semester Ganjil MTs Daarul Huffazh Tahun Pelajaran 2015/2016. Gedong Tataan, Pesawaran

Munawwir, A. Warson. 1997. Kamus Arab -Indonesia. Surabaya: Pustaka Progressif.

Radliyah Z, M.Ag Metodologi dan Strategi Alternatif Pembelajaran Bahasa Arab , Pustaka Rihlah, Group. Yogyakarta.

Sehri, Ahmad. 2010. Model Pengajaran Nahwu dalam Pengajaran Bahasa Arab .

Singgih, Muhammad, 2018, Penerapan Metode Qowaid Wa Tarjamah Untuk Meningkatkan Motivasi Dan Prestasi Belajar Bahasa Arab Siswa Kelas X 
Semester Genap Sma Al-Kautsar Bandar Lampung, Jurnal Annaba ; Pemikiran dan Penelitian Pendidikan Islam, 1 (2), 1-9

Sya'bani, Zaky, Muhammad, 2019, Analisis Kemampuan Mengubah Pronomina (Isim Dhomir) Mahasiswa Semester Ib Akhwat STIT Darul Fattah Bandar Lampung, Jurnal Annaba ; Pemikiran dan Penelitian Pendidikan Islam, 2 (2), 10-20

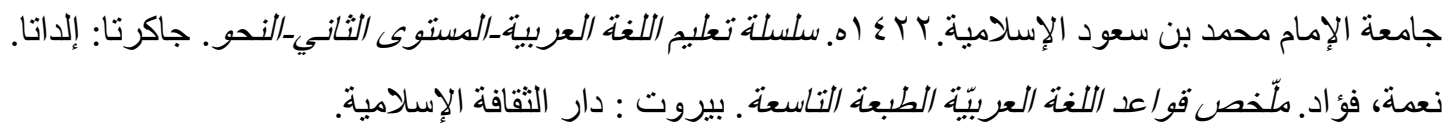

